\author{
A.T. Alimbayeva' ${ }^{1}$ iD , A.K. Sadykova² ${ }^{\text {iD }, \text { B.A. Kaljanova }}{ }^{1}$ iD \\ ${ }^{1}$ Al-Farabi Kazakh National University, Kazakhstan, Almaty, \\ e-mail: alimbayeva.adil@gmail.com,e-mail: alinmary@mail.ru \\ ${ }^{2}$ Ablai Khan Kazakh University of International Relations and World Languages, \\ Kazakhstan, Almaty, e-mail: sadyk_3008@bk.ru
}

\title{
TO THE PROBLEM OF FORMING FOREIGN LANGUAGE COMMUNICATIVE COMPETENCE OF PRIMARY-SCHOOL STUDENTS
}

The article is devoted to the issue of formation of primary-school students' foreign language communicative competence. At the present stage of development, the goal of foreign language education is to achieve foreign language communicative competence by students, that is, the ability and real readiness of pupils to carry out foreign language communication and seek the mutual understanding with native speakers of a foreign language. The advisability of forming a foreign language communicative competence at the primary-school age stage is confirmed by numerous studies, both in our country and abroad. A foreign language should be considered as a means of understanding the picture of the world, acquisition values created by other peoples. The paper considers the components of communicative competence, as well as the methods and technologies of its formation at the foreign language lesson. An experimental-pedagogical research was conducted in which 75 high school students of the 4th grade of primary school took part. The method of using active methods of teaching and communication of participants was used. At the stating stage, it was revealed that $60 \%$ of students are communicative active, and $40 \%$ - communicative passive. Taking into account the individual characteristics of children, classes were held on the updated methodology.

Key words: schoolchildren, second language acquisition, foreign language, communicative competence.

\author{
А.Т. Алимбаева', А.К. Садыкова², Б.А. Калжанова ${ }^{1}$ \\ 'Ә^-Фараби атындағы Қазақ ұлттық университеті, Қазақстан, Алматы қ., \\ e-mail: alimbayeva.adil@gmail.com, e-mail: alinmary@mail.ru \\ ${ }^{2}$ Абылай хан атындағы Қазақ халықаралық қатынастар және әлем тілдер университеті, \\ Қазақстан, Алматы қ., e-mail: sadyk_3008@bk.ru
}

\section{Бастауыш сынып оқушыларының шетел тілді коммуникативтік құзыреттілігін қалыптастыру мәселесіне}

\begin{abstract}
Мақала бастауыш сынып балаларының шетел тілінің коммуникативтік құзіреттілігін қалыптастыруға арналған. Қазіргі кезеңнің шетел тілін оқытудың мақсаты - оқушылардың коммуникативті құзіреттілігіне жету, яғни оқушылар шетел тілін меңгеруге және шетел тілінің ана тілдерімен өзара түсінісуге қабілеттілігі мен нақты дайындығы. Бастауыш мектеп жасында шетел тілінің коммуникативті құзіреттілігін қалыптастырудың орындылығы біздің елімізде Ае, шетелде де жүргізілген көптеген зерттеулермен расталады. Шетел тілі әлемнің бейнесін түсіну, басқа халықтар құрған құндылықтармен танысу құралы ретінде қарастырылуы керек. Мақалада коммуникативтік құзіреттіліктің компоненттері, сонымен қатар оны шет тілі сабағында қалыптастыру әдістері мен технологиялары қарастырылған. Бастауыш мектептің 4 сыныбының 75 оқушысы қатысқан тәжірибелік-педагогикалық зерттеу жүргізілді. Оқушылардың коммуникативтілігі және белсенді оқытуды пайдалану әдістемесі қолданылды. Тұрақтандыру кезеңінде оқушылардың 60\% коммуникативті белсенді, ал 40\% - коммуникативті енжар екендіктері анықталды. Сабақтар оқушылардың жекедаралық ерекшеліктерін есепке ала отырып, жаңартылған әдістеме бойынша өткізілді.
\end{abstract}

Түйін сөздер: бастауыш мектеп оқушылары, шет тілін меңгеру, шетел тілі, коммуникативті құзіреттілік. 


\title{
А.Т. Алимбаева ${ }^{1}$, А.К. Садыкова², Б.А. Ка^жанова ${ }^{1}$ \\ 'Казахский национальный университет им. аль-Фараби, Казахстан, г. Алматы, e-mail: alimbayeva.adil@gmail.com, e-mail: alinmary@mail.ru ${ }^{2}$ Казахский университет межАународных отношений и мировых языков имени Аблай хана, Казахстан, г. Алматы, e-mail: sadyk_3008@bk.ru \\ К проблеме формирования иноязычной коммуникативной компетенции млаАших школьников
}

\begin{abstract}
Статья посвящена проблеме формирования у детей младшего школьного возраста иноязычной коммуникативной компетенции. На современном этапе развития целью иноязычного образования является Аостижение учащимися иноязычной коммуникативной компетенции, то есть способности и готовности школьников осуществлять иноязычное общение и добиваться взаимопонимания с носителями иностранного языка. Целесообразность формирования иноязычной коммуникативной компетенции на этапе млаАшего школьного возраста подтверждается многочисленными исследованиями как в нашей стране, так и за рубежом. Иностранный язык Аолжен рассматриваться как средство познания картины мира, приобщения к ценностям, созАанным другими народами. В работе рассматриваются компоненты коммуникативной компетенции, а также методы и технологии ее формирования на уроке иностранного языка. Автор излагает теоретические подходы к исследованию коммуникативной компетенции Аетей младшего школьного возраста и Аает обоснование эмпирического исследования иноязычной коммуникативной компетенции на начальном этапе овладения иностранным языком. Проведено опытно-педагогическое исследование, в котором приняли участие 75 школьников 4 класса начальной школы. Была использована методика применения активных методов обучения и коммуникации учащихся. На констатирующем этапе выявлено, что $60 \%$ учеников являются коммуникативно активными, а 40\% - коммуникативно пассивными. С учетом индивидуальных особенностей детей проведены занятия по обновленной методике.

Ключевые слова: младшие школьники, усвоение второго языка, иностранный язык, коммуникативная компетенция.
\end{abstract}

\section{Introduction}

In the context of modernization of the education system, multilingualism and multiculturalism, the problem of the quality of primary foreign language education is of particular importance. The strategy of early school education in foreign languages should be built in accordance with the new priorities of the school in the $21^{\text {st }}$ century, the school as a source of development of abilities and creative activity of learners who are able to solve problems in the form of communication independently. The educational discipline "Foreign Language", as others disciplines has great potential impact on the learner's personality, as it comprises all spheres of human activities and human communication. Primary-school age is an optimal period of active learning of social behavior, the art of communication, acquisition of communicative and speech skills. In the conditions of modern school possibilities for communicative and psychological adaptation of the person to the new language world, different from the world of native language and culture, the foundations of communicative competence can be realized through active methods and interactive technologies, which largely determine the socio-cultural and communicative development of learners.
The aim of the research is the theoretical justification and development of methodology for the formation of foreign language communicative competence of primary-school students.

Materials and methods research. The authors used methods based on a theoretical analysis of modern scientific literature on research issues, generalization of pedagogical and methodological works in the field of preparing primary-school students' foreign language communicative competence. The research study is organized on the basis of empirical methods: questioning, observation, as well as mathematical and statistical methods of processing the obtained data.

\section{Literature review}

Foreign language education as one of the components of the general system of national education can not be considered out of connection with the environment in which it functions and develops. The expanding integration processes and the deepening of international interaction and cooperation over the past decade have stimulated the progressive development of foreign language education. The educational system of Kazakhstan has undergone significant positive changes, both in content and in organizational terms: the study of foreign languages (FL) is recognized as socially- 
significant warranty of practical and professional life of a person in the modern multilingual and multicultural globalized world; the place of a foreign language as the language of international communication is determined; the need to introduce early learning of foreign languages with further improvement and deepening of their mastery in the variable successive structure of educational institutions of basic, secondary specialized, postsecondary professional and higher education is realized (Kunanbayeva, 2006). Cognitivelinguacultural methodology as a universal conceptual basis of the modern theory of foreign language and multilingual education provides an innovative approach to modeling the educational process of learning a language, to the creation of domestic international adaptive level models of language education in the conditions of multilingualism; defines learning levels as the levels of achievement of intermediate and final results, as well as significantly changes the practice of organizing the educational process (Kunanbayeva, 2010).

In the conditions of sociocultural transformations of Kazakhstani society and the alignment of the school, aimed at identifying the abilities of each student, particular importance is attached to the initial stage of education, which is currently undergoing a new period of development. The novelty of the stage is associated with a radical change in the priorities of primary education, in the foreground of which is the general cultural, personal and cognitive development of primary-school students as its goal and main result (A.G. Asmolov, V.V. Rubtsov, D.I. Feldstein, V.D. Shadrikov). Therefore, in 1998, in the framework of the Council of Europe project "Learning a Language for European Citizenship" in Austria, at the international seminar devoted to the problems of early foreign language learning, the results of many years of experiments and scientific research, related to the introduction of the subject "Foreign Language" in the primary-school curriculum of the member states of the Council of Europe were summed up and discussed. Recommendations for the primaryschool curriculum were formulated at this seminar, the implementation of which was considered as the basis for the successful implementation of a foreign language at the initial stage of training in the countries of the Council of Europe. The most relevant areas of research were identified related to the identification of age-specific models of foreign language acquisition specific to children and factors affecting the process of teaching foreign language to children. These areas have focused our attention on the problem of studying the patterns of mastering a foreign language by children in artificial conditions, and not from the perspective of the teacher's activity, but from the point of view of the specifics of the processes of foreign language acquisition by a child of primary-school age. Thus, there are sociocultural prerequisites for introducing the concept of "primary education in a foreign language" in the terminological system of science. We include the following points to these sociocultural prerequisites: recognition of the importance of primary language education at the state level; the demand for a foreign language in society and parents' understanding that a foreign language is not only evidence of education, but also the basis for the future social and material well-being of their children; models for the development of education in elementary school have been created and exist.

Analysis of the current educational situation in the field of FL allowed us to identify the main trends and urgent problems, to which we refer: the aim and means of FL acquisition in primary-school in the light of the new state requirements to the primary foreign language education; the continuity of the various stages of school foreign language education; the successful formation of educational activities in acquisition of foreign language speech activity; the creation of motivation in FL acquisition as a means of communication and cognition; the regularities of FL acquisition by the primary-school students; the development of creative foreign language speech of the primary-school students; the cognitive potential of formation foreign language speech activity in primary-school age; spiritual and moral upbringing of primary-school students by the aid of the subject "Foreign Language"; evaluation of learners' educational results. There are objective trends that determine the need for a new theoretical vision of how the FL acquisition in primary-school should be organized, and what is the significance of primary foreign language education for the implementation of its new tasks. The communicative development of primary-school students in the system of FL acquisition is focused not only on the success of their foreign language communication skills, but also on increasing their success level while communicating in their native tongue. Nowadays, communicative goal-setting in primary-school age is becoming the subject of communicative competence formation. Primary-school students should be able to receive information on the issue of their interest. The basis of this goal is the cognitive interest of primaryschool student, i.e. the aim of communication is the request of information. At a primary-school age the pupil acts as a source of information, not just as a 
consumer. In this case, the aim of communication becomes the presentation or exchange of information. Communicative development as a result of primary education is a complex and new formation; it is necessary to identify its components and determine the ways of its development.

The analysis of the literature has shown that certain scientific prerequisites for solving the problem of communicative ability formation of primary-school students are accumulated; indicating that the educational process aimed at mastering the communicative activity will contribute to the harmonization of personal development. A child, who is mastering a foreign language in a modern primary-school, is not just an imitator repeating the learned, but a person learning to make independent decisions. The task is to help the student learn to "create" speech in a foreign language as well as to produce it in his/her native language (Rumyantseva, 2004). The way of development of the primaryschool student's language personality is not an imitation and reproduction, but creativity of a new language acquisition, which becomes possible under the condition of foreign language speech ability formation. It should be noted that the effectiveness of foreign language acquisition largely depends on how the beginning of the first year is planned, in the course of development of which, the types of speech activity have a priority role.

Solving the task of determining the subject and content of communicative competence formation of primary-school student has required separation of the concept of competence as a planned result at the level of primary education; determining its structural components and content. Thus, in April 1997, the Council of Europe adopted a document entitled "Modern Languages: Learning, Teaching, and Assessment. A Common European Framework of reference". According to the rendered geopolitical conditions, the idea of creating such a document arose in 1991. The concept of a new Europe: Europe without borders, in which the spheres of international cooperation are significantly expanding, it is necessary to draw special attention to the problems connected to the acquisition of foreign languages. The Committee of Ministers of the Council of Europe urged the relevant organizations of different countries to accept the necessary steps to establish an effective common European system of information exchange (using all the possibilities of the latest information technologies) regarding practical mastering of foreign languages and theoretical research in this field. Communicative language competence consists of three components in this document: linguistic, sociolinguistic, and pragmatic. The linguistic component includes phonological, lexical, grammatical knowledge and skills, regardless of sociolinguistic values and pragmatic functions of their realization. The sociolinguistic component defined by the sociocultural conditions of language use, comprises a connection between communicative and other competences. The pragmatic component apart from the general competences includes extralinguistic elements providing communication (such elements include, for instance, facial expressions, gestures, etc.).

There is no uniform understanding of this concept in the scientific literature. In defining its formulation, we relied on various studies on communicative characteristics and skills that dealt with the establishment of the communicative structure of the personality and the structure of communicative skills, according to which the communicative core of the personality encompasses personality qualities through their orientation, attitudes, value orientations and worldview are determined. We have found different interpretations of this concept in various scientific literature and researches of both domestic and foreign scholars. K.S. Krichevskaya's points out that communicative competence is integrative in its essence and includes several components: communicative skills in speaking, listening, reading, and writing; linguistic knowledge and skills as a "building material" for the acquisition of language, generation and recognition of information; language and country studies for providing secondary socialization, sociocultural background, without which it is impossible to form a communicative competence. Thus, K.S.Krichevskaya believes that in the process of achieving the planned result, a whole complex of instructional, educational and developing tasks are achieved and implemented. The insertion in the target setting of foreign language teaching, and, consequently, in the content of teaching country studies knowledge as a full component will ensure learner's acquisition of another national and cultural realia, the expansion of their general worldview, which will also increase interest to the studied foreign language and develop persistent motivation (Krichevskaya, 1996).

After examining different approaches to consider the concept of "communication competence", we have specified this concept. From our point of view, students' communication skills are an integral personal characteristic, social adaptability, the successful use of verbal 
and non-verbal means of communication, as well as the ability to adequately reflect on the mental state and personality of another person, ensure prediction of the behavior of the perceived person and contribution to one optimal solution of various communication problems. Speech communication is the main condition for the development of children's speech and mentality, and the primary-school age is a sensitive period of internal speech formation, development of empathy, monologue speech and the basis of writing skills (Asmolov, Burmenskaya, Volodarskaya, et al., 2008). The social role of an individual requires communicative competence in the social environment. Communication competence is necessary for the correct assessment of communication in social communication situations, by the goals or the structure of the goals, rules of conduct, the role system characteristic of the situation, the repertoire of elementary actions, and the available concepts that define the situation, their understanding, their environment, language and speech means.

An analysis of communicative competence's components allows us to say that the points of view considered by us are extremely heterogeneous and universal in terms of the age of students. It is necessary to determine a more clear structure of communicative competence in relation to primaryschool age and the technological base for teaching a foreign language within the framework of the issue that we are studying. Therefore, we have thoroughly considered this information and tried give it an extensive reflection in our research. The basic component in all the models of "communicative competence" that we have examined is language (linguistic) competence, which involves mastering new language tools in accordance with the topics, areas, and situations of communication, mastering the knowledge of the linguistic phenomena of the language being studied, different ways of expressing thoughts in the native and studied languages. The leading role in an acquaintance with a new linguistic community belongs to the language, which introduces the child into the communication of cultures and actually communicative activity in another language, the development of which is speech competence (types of speech activity: speaking, listening, reading, and writing). While working on the speech competence of primaryschool students, the teacher develops the ability to navigate in various speech situations and adequately realize learner's communicative intentions. Learning a language cannot be accompanied only by the study of a foreign language culture in its comparison and juxtaposition with native culture. It is impossible to form a communicative competence even to a limited extent without knowledge of the sociocultural background; therefore, it is important to begin the formation of sociocultural competence from the initial stage of language learning. Introduction to a different culture allows primary-school students to become aware of herself/himself as a person belonging to another sociocultural community, and fosters tolerance and respect for another people's way of life.

Based on the main objectives, we can conclude that the emphasis of foreign language teaching is shifting from language to speech as a system. Considering the aims of each type of speech activity, we can distinguish the most prominent ones: in speaking - the ability to competently transmit information through oral speech; in writing - the ability to correct statements through writing; in reading - the skills of reading authentic texts; in listening - the skills of understanding speech in the situations of real conversation.

Starting from the primary-school actions and operations specific for each subject must be supplemented by universal (metasubject) educational actions (Asmolov, Burmenskaya, Volodarskaya, et al., 2008). Only if the primary-school student will acquire the necessary ways of interaction, then helshe has a communicative need and value attitude to communicative activities, readiness to apply the knowledge about communication. Subsecuently, it is necessary to give the child the freedom of choice in communicative activities in the formation of communicative universal educational actions: the freedom of choice of communication goals (Why shall I communicate?), the freedom to choose the object of communication (Whom shall I communicate with?) and the freedom to choose how to communicate (How shall I communicate?), S.G. Batyreva (2017) thinks.

\section{Methods and technologies}

As it is known, primary-school age is a significant stage of human development. The child's social status and social role changes as the school studies start. $\mathrm{He} / \mathrm{She}$ begins to engage in socially useful activities; his/her actions become socially-significant and evaluated. The ability to communicate in a foreign language is a key ability that determines the personal development of the primary-school student. Since primary-school is the first link in the general system of school education, its task is to provide the basis of such ability, allowing children's foreign language communication and interaction at an elementary 
level, taking into account the real needs and interests of children of this age. The cognitive and intellectual sphere of activity is changing; the formation of strong-willed qualities is taking place. Along with all new growth, very often the primary-school student experiences difficulty in solving educational and communicative tasks, until he/she formulates the difficulties aloud. "Thinking aloud, according to scientists, facilitates and forms thinking as itself" (Vygotsky, 1984, p. 93). There is a transition from visual and imaginative thinking to verbal and logical at this age. All the psychological characteristics of primary-school students, determine the motive of a communicative activity. Children's language typically has been studied from a developmental perspective in early childhood education. Vygotsky's theory of development emphasizes that children actively construct meaning through interaction with others. Thus, in the conditions of distribution of mainly communicative-oriented training there is a need to apply active methods of teaching. Active methods of teaching are used systematically to ensure the activity of learners and the diversity of their mental and practical activities in the process of acquiring new educational material. The purpose of such methods is to activate the abilities and skills of learners, to involve them into educational process, into independent mastery of educational material.

A.M. Smolkin (1991) characterizes active learning methods as ways of enhancing learning and cognitive activity of students, which lead them to the active and practical activity in the process of mastering the material. Interactive process is characterized by high intensity of communication, change and variety of activities, and purposeful reflection. The principle of interactivity can be traced in most modern educational technologies, which are based on a personality-oriented approach. The advantages of this approach consist in stimulating the development of cognitive and creative abilities of learners, creating a situation of success in which the main actor is the learner himself/herself, actively interacting with other participants of the educational process. Personalityoriented approach helps students to realize that learning a foreign language is more connected with their personality and their interests than with the methods and means of teaching set by the teacher. The existing gap between the intellectual abilities of pupils, their interests and what they can actually express in a foreign language gradually destroys the motivation that was supported at the beginning by the novelty of the subject, the aspiration, willingness and desire to learn to communicate in the target language. Therefore, the use of role-playing games, dramatization-games, staging is one of the effective means of teaching a foreign language at the initial stage. The use of the role-based approach focuses not only on the development of communication skills, but also on the successful psychological adaptation and socialization of schoolchildren, the development of the potential of the personality and their desire for self-improvement. Its application in many ways makes it possible to avoid the inhumanity of education and training, since the students are involved in activities that are completely intellectual and moral.

The leading activity in the primary-school age is the learning with the elements of game, which determines the development of child's all mental processes, sets the emergence of majormental growth. The game, as we know, is the main mechanism for the development of the child's personality. Game techniques in foreign language lessons should be an integral part of the methodical organization of the lesson to create an emotionally-favorable communicative situation in the classroom. Welldesigned and methodically well-organized game is the technique of training which allows solving problems of a practical, educational, developmental and educational nature. Dramatization-game gives learners the opportunity to understand and study the learning material from different positions, feeling themselves in a certain role. This technique motivates speech activity, as learners find themselves in a situation where the need to say, ask something, find out, justify, abstracting from the educational process is actualized. Children's participation in games creates partnerships between children, and group support creates a sense of security, and even the most timid and anxious children overcome fear. The reason why the dramatization-game is close to children was perfectly formulated by L.S. Vygotsky (2001). Drama, based on the action performed by the child himself/herself, most closely, effectively and directly connects his/her artistic creativity with a personal experience. And this dramatization of impressions gives the child a great pleasure.

Thus, role-playing games aimed at the formation of communication skills and abilities to listen and hear the interlocutor, adapt to the partner and defend their point of view, expanding the boundaries of creativity by immersing in the game-improvisation and enriching the idea of the game with information replenishment, allow fully realize the potential of a foreign language for the formation and development of the creative language personality of children. Such games include "Verbal relay race", "Association" and 
etc. The solution of creatively oriented intellectual tasks in the role-playing game on the material of a foreign language allows realizing the possibilities of a foreign language to enrich the emotional sphere of personality, prevention and therapy of language anxiety, formation and strengthening of internal motivation of foreign language speech activity and communication, optimization of personal selfesteem, purposeful development of all structural components of pupils' creative language personality.

A.V. Konysheva (2007) cites in her work five exercises based on the techniques of drama:1) Warming-up + observation, the goal of which is to help all members of group to achieve psychological unity, to channel thought and feelings on further fulfilling the task (not more than 5 minutes); 2) Creation and invention - drawing, sketches, use of improvised material; 3) Word-play - the more we experiment with different combinations, the better we learn the potential of the language, and the important thing is not the result (verse, scene), but the process of experimenting with the language; 4) Problem-solving involves the practice of thinking in English when viewing information, following instructions, which distracts from the mechanical learning of the material; 5) The use of literary texts, poems, songs: tasks are not limited to working with texts; texts are only an incentive for further work.

Puppet Theater plays a special role in the development of speech. It allows establishing cause-andeffect relations between the actions and changes of a condition of a doll that allows improving communication skills and culture, to observe that movements and speech coincided. Children's acquaintance with the fairy tale can begin with a detailed commented reading of the text, and then lead the children to the solution of problematic issues. These are issues that contribute to the active inclusion of children to the process of communication, because they can express their opinions on this issue. It is important to the instructor to teach the child to express his/ her thoughts correctly, as well as to learn to respect his classmates and to be able to listen to them. They prove their own answers with the examples from the text, mark the positive and negative traits of the characters. All these factors help to organize communication, because every child has the opportunity to talk with an interested interlocutor. Thus, one of the main conditions for the organization of a dialogue is the creation of an atmosphere of trust and empathy, freedom and mutual understanding, cocreation of equal and different.

Working with the texts using the method "Mosaic" allows young learners to obtain a large amount of information in a short time. This method initiates interest, encourages putting questions, enables learners to take an active part in the learning process and share their knowledge with each other. Each learner (subgroup) reads the text of a small volume, and then looks for a partner who has read another text. After discussion of the texts, making the necessary notes, learners change partners. Each learner masters all the texts and, systematizing them, gets a general picture of the situation and problems.

Thus, the primary foreign language education can be defined as a holistic process of education, upbringing and development that contributes to the development of the experience of independent language activity in a foreign language, to the spiritual enrichment of the students' personality and to the formation of their learning and communication culture. The semantic content of initial training in a foreignlanguageisrevealed by the following concepts: morality, value (motivational-educational aspect), development and language creativity (operationalactivity aspect) as well as learning, communication and culture (cognitive-communicative aspect). A foreign language is successfully mastered through an organic combination of external and internal (independent), i.e. comprising a harmonious unity of learning and teaching.

\section{Methodological model}

It should be noted that modern primary education is based on integrated learning, as this is associated with updating the content of education. These innovations help to form a stable interest in learning, form the skills of learning activities. The uniqueness of integrated learning lies in the desire of teachers to diversify the school life of students and to encourage interest in cognitive communication, in school, in the subject, as well as in lesson. Integrated teaching helps to meet the needs of younger students in the development of motivational, intellectual, emotional and other areas (Zhekibayeva, et al., 2019).

The general conceptual idea of the study is that on the basis of the understanding of learning as communication, a communicative educational environment is created, thanks to which children develop communicative skills on the basis of their own positive experience of educational communicative activity and thereby rise to a higher level of their communicative development. Justifying the process of formation of communicative competence of primary-school students in the communicativeactivity educational environment, we determine the unity of the system as its methodological basis, 
personality-centered and activity approaches. The systematic approach provides consideration of the process of formation of communicative competence as multidimensional system with allocation of parameters, criteria and levels. The approach to learning as communication focuses on the recognition of the leading role of communication in the development of personality, on the existence of a connection between training and education, on the understanding of the didactic process as a communicative process. The activity approach assumes the organization of communicative activity around subject activity of primary-school students. The personality-centered approach ensures a creation of optimal conditions under which students realize their existing abilities to communication, increasing the level of communicative success.

The principle of speech activity involves the creation of problem tasks that contribute to the activation of cognitive activity of students and make it necessary to discuss them. The principle of individualization can be considered the heart of communicative interaction, one of the main means of creating motivation. In the lessons, it is necessary to take into account the learners' peculiarities, their interests, and choose the most relevant topics for discussion, such as "Acquaintance", "Family", "Seasons", "Country of language under study", "Music», etc. In this regard, the interrelated components of the model are identified, which are combined into four blocks: target, program-content, procedural and evaluative-productive.

The target block includes a set of orientations of the initial foreign language education, which may be significant in the communicative aspect: it reflects the goal, methodological basis, and peculiarities of the communicative competence of primary-school children, suggesting the result of its formation in the form of positive experience of educational communicative activity, manifested in the desire to engage in educational communication at their level of development and training.

The program-content block characterizes the filling of the process of forming the communicative competence of primary-school children in a foreignlanguage educational environment through the creation of a program of experimental training that illustrates the way to implement the presented model. It contains all the necessary information regarding the complex of interrelated circumstances of the learning process: possible forms, methods and tools, as well as the content of communicatively directed tasks in specially organized situations of educational communication.
The procedural block reflects the sequence of methods, technologies and techniques of the formation of communicative competence and provides their implementation into the process of forming the communicative competence of primary-school children through the functioning of the didactic mechanism (active methods and technologies), the creation of organizational and didactic conditions that ensure the formation of the communicative competence of primaryschool children in a foreign language educational environment. Game activity has the greatest impact on primary-school children communicative competence development, namely on the formation of: educational-cognitive component (to generate ideas, choose the best solution, evaluate the course and result of their activities ); socio-cultural component (to study culture of the target language, to learn the culture means, collaborate in the learning process, provide assistance to classmates and accept their help, monitor the progress of joint work and direct it in the right route); regulatory-compensatory component (to independently search for the necessary information, identify information and to be able to apply the acquired knowledge); language component (to demonstrate grammatical and lexical knowledge and skills, use of various visual aids, language awareness); speech-communicative component ( to answer questions and ask them, respond to statements).

The evaluative-productive block of the model determines the criteria for the manifestation of communicative competence of students in the educational environment of primary-school, implements diagnostic methods that make it possible to determine the level of formation of communicative competence of primary-school students.

We have defined the following criteria that reflect its components and the results presented to assess the level of formation of communicative competence. Thus, a language or linguistic criterion that provides orientation in activity, assimilation of language material and its use in speech, assumes the formation of language skills and abilities (sound reproduction, lexical side of speech, grammatical structure of speech). Speech communicative criterion, which allows to navigate in complex communicative situations, implies the formation of abilities to communicate, to keep the communication process, and terminate the communication; to understand what is said by the interlocutor (the goal is an adequate understanding once and at a normal pace of presented information); ask the interlocutor, if 
there is a need in clarification and explanation; to express basic language functions (to confirm, to argue, to question, to approve, to promise, to agree, to learn, to ask, etc.); to speak comprehensively, logically, coherently, and productively, passing meaningful for the interlocutor information using the most suitable communication tactics; to read authentic texts with understanding of the substantive content; reading and finding simple authentic texts; writing short statements based on a sample or a plan, and etc. Sociocultural criteria is manifested in the combination of knowledge, skills, and personality qualities of younger students, which provide effective socialization in a multicultural environment in accordance with age characteristics. The sociocultural criterion includes a set of knowledge about the values, behavioral patterns, customs, traditions, cultural achievements inherent in the society and the ability to live in this society, respecting the traditions of all peoples inhabiting it. Compensatory criterion involves the ability of guessing the meaning of unfamiliar words in context to ask again in the conversation, using facial expressions, replacing unfamiliar words with words-analogues; the ability to find a way out of the situation due to the lack of foreign language means to restore interrupted communication process; skills of nonverbal communication, anticipating or accenting parts of the verbal message; filling the pauses of the word search, replacing a single word or phrase, which include paralinguistic means (intonation, pause, tempo, volume, rhythm, tonality, melody), extralinguistic (laughter, crying, various noises), and kinesic (gestures, facial expressions, eye contact). The educational-cognitive criterion assumes the formation of the following skills and abilities as a motivation for learning: the formation of goal-setting and the expression of educational and cognitive interest; analysis and synthesis; construction of a new way of action and modeling; self-assessment and self-awareness of activity, as well as the level of self-regulation in intellectual activity; the ability to self-observe and selfevaluate language and speech actions; to compare the language phenomena of native and foreign languages at the level of individual sounds, letters, words, phrases, simple sentences; work in pairs, groups when performing foreign language actions, etc. Criteria and indicators of the formation of communicative competence of younger students served as an evaluation base for experimental work. For this purpose, three levels of formation of communicative competence of primary school children were identified: high, medium and low.

\section{The results of the experimental study and discussion}

Experimental work was carried out in three stages. At the ascertaining stage, the process of teaching a foreign language in primary classes, the use of active methods and technologies in the classroom were analyzed, the method of diagnosing the initial level of formation of communicative competence was developed. 75 students of the fourth grades, three teachers of English and 9 student-trainees participated in experimental training. The following research methods were used to implement the tasks: questioning, testing, conversation, observation, interviewing. The aim of the experimental work was to trace how the systematic use of active teaching methods at English lessons affects the formation of communicative competence and activation of cognitive interest of primary-school students.

The analysis of the educational process in a foreign language in primary classes and questionnaires showed that all teachers and students $(100 \%)$ consider the importance of the usage of active methods and technologies in the educational process, but the target orientation of their use was different for all. Such methods as test-interviews, observation and questioning were used to determine the initial level of foreign language communicative competence formation. During the experiment, it was found that the components of foreign language communicative competence are formed in students in different ways, which allows us to talk about the levels of formation: high, medium, low. The diagnostic results are given in the table.

The results of the ascertaining stage of the experimental work have shown that the degree of foreign language communication skills is low. This shows the need for targeted work on the formation of communicative competence in primary-school using active methods and technologies. The solution to this problem required the assignment of a number of didactic conditions for the development of a foreign language communication competence of elementary school students.

At the first stage forming experiment individual psychological features of learners of primaryschool age were studied and typological groups of pupils were defined on this basis, the complex of exercises and tasks on the basis of active methods and technologies for mastering a foreign language was developed and tested. M.K. Kabardov (2001) considers the function of communication as one of the main criteria of typological division of students. Thus, according to this criterion, there is a division into communicative type and non-communicative 
type. After processing the results of the survey of children and analysis of the data, it was revealed that
45 students $(60 \%)$ are communicatively active, 30 students $(40 \%)$ are communicatively passive.

Table 1 - The initial level of formation of a FL communicative competence of primary-school students

\begin{tabular}{|c|c|c|c|c|c|c|}
\hline \multirow{2}{*}{ The criterion of CC formation } & \multicolumn{4}{|c|}{ Number of students by level (out of 75) and \% (out of 100) } \\
\cline { 2 - 7 } & \multicolumn{2}{|c|}{ High } & \multicolumn{2}{|c|}{ Medium } & \multicolumn{2}{c|}{ Low } \\
\cline { 2 - 7 } & $\begin{array}{c}\text { Number } \\
\text { of } \\
\text { students }\end{array}$ & $\begin{array}{c}\text { \% of CC } \\
\text { formation }\end{array}$ & $\begin{array}{c}\text { Number of } \\
\text { students }\end{array}$ & $\begin{array}{c}\% \text { of CC } \\
\text { formation }\end{array}$ & $\begin{array}{c}\text { Number of } \\
\text { students }\end{array}$ & $\begin{array}{c}\% \text { of CC } \\
\text { formation }\end{array}$ \\
\hline Language & 17 & $22,7 \%$ & 24 & $32 \%$ & 34 & $45,3 \%$ \\
\hline Speech-communicative & 14 & $18,6 \%$ & 24 & $32 \%$ & 37 & $49,4 \%$ \\
\hline Socio-cultural & 12 & $16 \%$ & 23 & $30,7 \%$ & 40 & $53,3 \%$ \\
\hline Compensatory & 21 & $28 \%$ & 20 & $26,7 \%$ & 34 & $45,3 \%$ \\
\hline Educational-cognitive & 18 & $24 \%$ & 22 & $29,3 \%$ & 35 & $46,7 \%$ \\
\hline
\end{tabular}

At the second stage experimental learning based on a phased methodology of formation of communicative competence of primary-school students by using active methods and technologies took place, and was also the analysis of the results and subsequent conclusions. While studying topics ("Acquaintance", "Family", "Seasons" etc.), students developed elementary communicative skills in speaking, listening, reading and writing, ensuring communicative and psychological adaptation of students to the new language world by presenting real communicative situations.

Two groups were formed out: experimental and control. In the control group: the training was carried out according to the traditional program. In the experimental group: the training was carried out on the basis of the developed step-by-step methodology for the formation of communication skills on the basis of active methods and technologies. The experimental work carried out showed that the level of communication skills of elementary school students in the field of foreign languages increased during the experimental work with active methods and technologies. This fact shows that we have correctly taken into account the didactic conditions for the development of foreign language communication skills. The results are shown in the table and in the diagram below.

Table 2 - The final level of formation of FL communicative competence of primary-school students

\begin{tabular}{|c|c|c|c|c|c|c|}
\hline \multirow{2}{*}{ The criterion of CC formation } & \multicolumn{4}{|c|}{ Number of students by level (out of 75) and \% (out of 100) } \\
\cline { 2 - 7 } & \multicolumn{2}{|c|}{ High } & \multicolumn{2}{c|}{ Medium } & \multicolumn{3}{c|}{ Low } \\
\cline { 2 - 7 } & $\begin{array}{c}\text { Number of } \\
\text { students }\end{array}$ & $\begin{array}{c}\% \text { of CC } \\
\text { formation }\end{array}$ & $\begin{array}{c}\text { Number of } \\
\text { students }\end{array}$ & $\begin{array}{c}\% \text { of CC } \\
\text { formation }\end{array}$ & $\begin{array}{c}\text { Number of } \\
\text { students }\end{array}$ & $\begin{array}{c}\% \text { of CC } \\
\text { formation }\end{array}$ \\
\hline Language & 53 & $70,6 \%$ & 16 & $21,3 \%$ & 6 & $8,1 \%$ \\
\hline Speech-communicative & 52 & $69,3 \%$ & 17 & $22,6 \%$ & 6 & $8,1 \%$ \\
\hline Socio-cultural & 54 & $72 \%$ & 14 & $18,6 \%$ & 7 & $9,4 \%$ \\
\hline Compensatory & 50 & $66,7 \%$ & 15 & $20 \%$ & 10 & $13,3 \%$ \\
\hline Educational-cognitive & 53 & $70,6 \%$ & 14 & $18,6 \%$ & 8 & $10,8 \%$ \\
\hline
\end{tabular}


Thus, foreign language communicative competence is therefore a prerequisite for effective communication in a foreign language. The formation of foreign language communicative competence in primary-school students is a complex and multilevel educational process, which should be ensured by the consistency and networking of goals, objectives, content and technologies for mastering a foreign language and the sequence of pedagogical influences.

\section{Conclusion}

While analyzing the literature, we understand that the goal of modern school is to prepare a person with the ability to think and feel who not only has knowledge but also knows how to apply this knowledge in life. Every student must be able to act and solve problems in every situation. Foreign language communication is not only the process of transmitting and receiving information, but also the regulation of relations between partners, the establishment of various kinds of interaction, the ability to evaluate, analyze the communication situation, subjectively evaluate your communication potential and make the necessary decision, which contributes to a significant increase in the effectiveness of communication. Mastery of communication skills is a prerequisite for the formation of a socially active person. One of the most important tasks of the modern learning level is therefore the development of communication skills. A number of factors influence the development of communication skills in primary-school children: taking into account the psychological characteristics of primary school children; differentiated approach taking into account the individual characteristics of elementary school students; Focus on the process of building communicative skills based on the positive experience of communicative activities by elementary school students. The use of a variety of activity technology methods and techniques and a competency-based approach is an effective means of developing communication skills.

\section{References}

1. Kunanbayeva, S.S. Kontseptsiya razvitiya inoyazychnogo obrazovaniya RK. - Almaty: Kazakh Ablai Khan University of International Relations and World Languages, 2006. (In Russian)

2. Kunanbayeva, S.S. Teoriya I praktika sovremennogo inoyazyichnogo obrazovaniya. - Almaty, 2010. (In Russian)

3. Rumyantseva, I.M. (2004) Psikhologiya rechi i lingvopedagogicheskaya psikhologiya. M.: PER SE; Logos, 319 p. (In Russian)

4. Krichevskaya, K.S. (1996) Pragmaticheskiye materialy, znakomyye ucheniki s kul'turoy i sredoy obitaniya zhiteley strany izuchayemogo yazyka. Inostrannyye yazyki v shkole, №1, pp. 13-17. (In Russian)

5. Asmolov, A.G., Burmenskaya, G.V., Volodarskaya, I.A., Karabanova, O.A., Salmina, N.G., Molchanov, S.V. (2008) How to design universal educational actions in primary school: from action to thought: manual for teachers. Ed. A.G. Asmolov. Moscow: Prosveschenie, pp.16-17. (In Russian)

6. Batyreva, S.G. (2017). Pedagogicheskiye usloviya formirovaniya kommunikativnoy kompetentsii mladshikh shkol'nikov: dissertation ... of the candidate of pedagogical sciences: 13.00.01, 195 p. (In Russian)

7. Vygotsky, L.S. (1984) Sobranie sochinenii: Tom 4. Detskaya psichologiya. - M.: Pedagogy, p. 93. (In Russian)

8. Smolkin, A.M. (1991) Methods of active learning. M.: Vyschaya shkola. (In Russian)

9. Vygotsky, L.S. (2001) Sobranie sochineniy: v 6 tomah. Ed. A.V. Granik. - M.:VLADOS, 342 p. (In Russian)

10. Konysheva, A.V. (2007) Angliyskiy yazyk. Sovremennyye metody obucheniya. Minsk: Tetra-Systems. - 352 p. (In Russian)

11. Zhekibayeva, B.A., Kalimova, A.D., Kolomiets, A.M. (2019) Diagnostika motivatsionnogo komponenta podgotovki budushchikh uchiteley k integrirovannomu obucheniyu. KazNU Bulletin. "Pedagogical Sciences”, Journal of Educational Sciences. № 2 (59) (In Russian)

12. Kabardov, M.K. (2001) Kommunikativnyye i kognitivnyye sostavlyayushchiye yazykovykh sposobnostey (Individual'notipologicheskiy podkhod): dissertation of psycholological sciences doctor. - M., 354 p. (In Russian) 